\title{
Environmental Changes and Fisherman Welfare in Coastal Area of Kendari Bay
}

\author{
Muhammad Aswar Limi ${ }^{1, ~ *, ~ L a ~ S a r a ~}{ }^{2}$, Taane La Ola ${ }^{1}$, Lukman Yunus ${ }^{1}$ \\ ${ }^{1}$ Department of Agribusiness, Faculty of Agriculture, Halu Oleo University, Kendari, Indonesia \\ ${ }^{2}$ Department of Fisheries, Faculty of Fisheries and Marine Sciences, Halu Oleo University, Kendari, Indonesia
}

\section{Email address:}

aswar_agribusiness@yahoo.com (M. A. Limi), lasara_unhalu@yahoo.com (La Sara), laola_taane@yahoo.com (T. La Ola), lukuyus@yahoo.com (L. Yunus)

${ }^{*}$ Corresponding author

\section{To cite this article:}

Muhammad Aswar Limi, La Sara, Taane La Ola, Lukman Yunus. Environmental Changes and Fisherman Welfare in Coastal Area of Kendari Bay. Agriculture, Forestry and Fisheries. Vol. 6, No. 1, 2017, pp. 20-25. doi: 10.11648/j.aff.20170601.13

Received: November 25, 2016; Accepted: December 14, 2016; Published: January 21, 2017

\begin{abstract}
The research objective is to assess the changes in coastal area of Kendari Bay and to describe fisherman welfare in Kendari Bay. The study conducted in May-June 2016 in coastal area of Kendari Bay. The research location was determined purposively. Research population included the head of the family of fisherman who lived in coastal area of Kendari Bay for 4,077 households, and 150 families was purposively chosen. The data analyzed using descriptive analysis, income analysis and welfare analysis. Based on research results, coastal area of Kendari Bay environment is threatened by land conversion and high sedimentation which leads to environmental change and implicate the marine and fisheries resources, so the fisherman have to adapt and look for new fishing ground area which may affect their income. Fisherman welfare is specifically affected by fishery resources in coastal area of Kendari Bay.
\end{abstract}

Keywords: Environmental Change, Welfare, Fisherman, Coastal Area of Kendari Bay

\section{Introduction}

Fisher communities is strongly dependent on coastal environment as the condition of coastal environment will have direct impact on their lives. It is associated with fishery resources that exist in the region, such as shrimp, fish, crab and oyster which are susceptible to both anthropogenic and naturalistic interferences. It establishes reciprocal relationship or relationship between man and nature [1]. A phenomenon illustrating this condition is environmental changes occurred in coastal area of Kendari Bay.

Kendari Bay is one of the coastal areas with estuarine ecosystems with total area of $\pm 19.05 \mathrm{~km}^{2}$ [2]. The formation of Kendari city closely related with the opening of Kendari port which becomes a significant aspect in the development of coastal region of Kendari with the total area of $165,785 \mathrm{~km}^{2}$ [3].

Kendari Bay acts as the gateway and transportation hub for the mobility of human and goods and also used as a public place for the community. It features with several public facilities such as public ports for goods and human between the islands, Pertamina port, fishing port, local transportation (motorboat), industrial area (12,387 business units consist of small, medium and large industries), travel agent, rowing sport, boat moorings, scientific activity/research, landing sites/fish market, the activities of farming and fishing, and several other activities (cultivation area) [4], [5], [6].

Kendari Bay is also an estuary of 13 rivers with three large estuary: Wanggu, Kambu, and Lahundape river estuary. Some rivers and watersheds, including Wanggu, which leads into the Kendari Bay poses damage threat especially with high economic activity in the region as well as the development that focuses in the coastal areaof the Bay.

The development in coastal area is aimed at improving fisherman welfare, so they should gain economic benefit from the development. Economic benefits in coastal area encourages the development of infrastructure around Kendari Bay. However, economic benefits around Kendari Bay causes sedimentation which increased from $1084285.7 \mathrm{~m}^{3}$ in 1960 to $55,304,766.7 \mathrm{~m}^{3}$ in 2010 with sedimentation rate of $54.220 .481 \mathrm{~m}^{3}$. Sedimentation is caused by $89 \%$ infrastructure development, $1.9 \%$ waste sedimentation and $9.2 \%$ soil 
erosion sedimentation [2]. Further, [7] the shallowing of Kendari Bayis caused by sedimentation as the result of development activities (anthropogenic erosion), soil erosion in the Watershed of Kendari Bay and waste sedimentation. In 2000, the shallowing occurred in Kendari Bay for 760,040 $\mathrm{m}^{3}$, in which $571,487 \mathrm{~m}^{3}(75.2 \%)$ was caused by sedimentation from development activities, 148,466 $\mathrm{m}^{3}$ $(19.5 \%)$ caused by sedimentation from erosion in the catching area, and $40,087 \mathrm{~m}^{3}(5.3 \%)$ is due to waste sedimentation. Waste sediment is generated from industrial and domestic wastes and other sediments which cause turbidity and impact marine ecosystems as well as impose damage to the coastal ecosystems of Kendari Bay.

The above conditions impact fishing activities, especially related to the utilization of fishery resource. This resource decreases with the increase in sedimentation in Kendari Bay, including shrimp, fish and crabs. Consequently, the fisherman find it difficult to fulfill their needs. That situation raises questions about the impact of environmental change on fisherman's income and welfare. Research objectives include determining the environmental changes in coastal area of Kendari Bay and assessing fisherman welfare in the coastal area of Kendari Bay.

\section{Methodology}

\subsection{Time and Place}

The study was conducted in May-June 2016 in the coastal area of Kendari Bay. The research location was determined purposively in accordance with research object on environmental change of Kendari Bay. The location is chosen because most of the population work as fisher.

\subsection{Research Population and Sample}

Research population include the head of the family of fisherman who lived in coastal area of Kendari Bay for 4,077 families [8]. They depend their liveson the exploitation of coastal area of Kendari Bay. The determination of number of samples used [9]

$$
n=\frac{N}{1+N e^{2}}
$$

Where:

$\mathrm{n}=$ Number of samples

$\mathrm{N}=$ Number of population

$\mathrm{e}=$ error tolerance $(8 \%)$

Based on the calculation using Slovin formula, the total research sample was 150 families. Research sampling conducted purposively, with the criteria: heads of fisherman families who had settled there for more than 10 years, aged more than 17 years, and married.

\subsection{Data Types and Sources}

The data used in this study include primary and secondary data. Primary data collected directly from fisherman in the field and secondary data obtained from the documentation and publication of the results of the observation

\subsection{Data Collection Technique}

Data collection technique is the way to obtain the necessary data. Data collection technique is influenced by data types and sources. Data research is based on the interview using questionnaire.

\subsection{Data Analysis Technique}

\subsubsection{Descriptive Analysis and Revenue Analysis}

Explorative descriptive analysis used to interpret secondary data into a translated description. [10] Explorative descriptive research aims to describe the state or the status of a phenomenon. This analysis is used to explore environmental changes occurred in coastal area of Kendari Bay and its impact to fishermen's income. Revenue analysis is conducted by using the formulation [11]

$$
\mathrm{I}=\mathrm{TR}-\mathrm{TC}
$$

Where:

$$
\begin{aligned}
& \text { I = Income (IDR / month) } \\
& \mathrm{TR}=\text { Total Revenue (IDR / month) } \\
& \mathrm{TC}=\text { Total Cost (IDR / month) }
\end{aligned}
$$

\subsubsection{Welfare Analysis}

One of the important factors to assess the impact of environmental change on fisherman is the level of welfare [1] There are several welfare standards commonly used in Indonesia, including the standard issued by World Bank and BPS. World Bank sets the revenue of USD 1/capita/day as the lowest absolute poverty line. Absolute poverty refers to the inability of a person to meet minimum needs of life [12]

According to BPS, poverty standard can be observed from various approaches. One of them is revenue approach, in which a person is considered as poor if his income is under specific threshold. Poverty threshold of Kendari according to BPS is IDR 255.229/capita/month [3].

\section{Results and Discussion}

\subsection{Overview of Research Location}

Kendari Bay is located in the capital of Southeast Sulawesi province as one of the coastal areas with estuaries ecosystem with total area of $\pm 19.05 \mathrm{~km}^{2}$ [2]. Kendari Bay has become an important port as it becomes the center of economic development in coastal area of Kendari Bay. It also determines the formation of Kendari, which adjacent with six districts and there are 45 urban villages which have the total area of $165.785 \mathrm{~km}^{2}$ with the population of 207.577 people and the number is constantly increasing [3]

Kendari Bay also is the estuary of 13 rivers, three of them are major rivers: river estuary Wanggu, river estuary Kambu, and river estuary Lahundape, and ten minor rivers: BenuBenua, Mandonga, Sodoha, Tipulu, Wua-Wua, Kemaraya, Anggoeya and Kampung Salo [5], [2], [13]. 
As other regions in Indonesia, Kendari only have two seasons: dry and rainy season. The season is influenced by wind direction blowing over the region. According to data of Meteorology, Climatology and Geophysics of Kendari Maritime Meteorology Station, in 2014, rain occurred in 172 days with rainfall rate of 2.263,6 mm and 2.102,6 hours of solar system. The air temperature is influenced by various factors. The difference in sea level, mountain areas and coastal areas result in temperature difference for each place in a region. Overall, the city of Kendari is an area with tropical temperature. According to data of Meteorology, Climatology and Geophysics of Kendari Maritime Meteorology Station, during 2014, the maximum average of air temperature was $31.8^{\circ} \mathrm{C}$ and the minimum average of air temperature $23.4^{\circ} \mathrm{C}$. The air pressure average was $1.010,5$ millibars with humidity average of 82 percent. The average wind speed during 2014 reached 5.60 knots [3]

\subsection{Demographic and Socioeconomic Condition}

According to Table 1, the number of residents in the district is directly adjacent to Kendari Bay has increased, with the average population growth of $3.51 \%$. The people live and settle in that region due to land conversion of aquaculture area into residential area.

Table 1. The number of residents in the district directly adjacent to Kendari Bayin 2012-2015

\begin{tabular}{llllll}
\hline \multirow{2}{*}{ No } & \multirow{2}{*}{ District } & \multicolumn{4}{l}{ Population (People) } \\
\cline { 3 - 6 } & & $\mathbf{2 0 1 2}$ & $\mathbf{2 0 1 3}$ & $\mathbf{2 0 1 4}$ & $\mathbf{2 0 1 5}$ \\
\hline 1 & Kendari & 25557 & 26870 & 27686 & 29605 \\
2 & West Kendari & 42928 & 45132 & 46505 & 49725 \\
3 & Mandonga & 36163 & 38021 & 39177 & 41891 \\
4 & Kambu & 27135 & 28529 & 29395 & 31433 \\
5 & Poasia & 24977 & 26260 & 27058 & 28932 \\
6 & Abeli & 22,438 & 23,591 & 24,307 & 25,991 \\
& Total & 179,198 & 188,403 & 194,128 & 207,580 \\
\hline
\end{tabular}

Source: [3], [14], [15], [16]

According to Table 1, the highest number of residents in the district directly adjacent to Kendari Bay in 2015 was in West Kendari districts for 49,729 in habitants and the lowest was in Abeli districts for 25,991 people. While the number of family with main occupation as farmer/fisher living in the district directly adjacent to Kendari Bay in 2013 can be seen in Table 2 below:

Table 2. The number of households of farmers/fishermen in the district adjacent to Kendari Bay in 2003 and 2015.

\begin{tabular}{llllll}
\hline & & \multicolumn{3}{c}{ Year } & \multicolumn{3}{c}{ Change } \\
\cline { 3 - 6 } No & District & $\mathbf{2 0 0 3}$ & $\mathbf{2 0 1 3}$ & $\begin{array}{l}\text { Household } \\
\text { Agriculture }\end{array}$ & \% \\
\hline 1 & Kendari & 1.119 & 486 & -633 & -56.57 \\
2 & West Kendari & 746 & 367 & -379 & -50.80 \\
3 & Mandonga & 1.373 & 618 & -755 & -54.99 \\
4 & Kambu & 576 & 196 & -380 & -65.97 \\
5 & Poasia & 1.100 & 529 & -571 & -51.91 \\
6 & Abeli & 2.184 & 1.881 & -303 & -13.87 \\
& Total & 7.098 & 4.077 & -3.021 & -42.56 \\
\hline
\end{tabular}

Source: [15]
In particular, data on the fisher household who settle along the coastal area of Kendari Bay is not available. However, based on the agricultural census [8], the number of family with main occupation as farmer/fishermen living in the district directly adjacent to Kendari Bay was 7,098 households. Compare with the results of agricultural census in 2013, there was a decline in the number of family with main occupation as farmer/fishermen into 4,077 households with the highest number was in District Abeli for 1,881 households and the lowest was in Kambu districts and West Kendari districts, respectively 196 and 367 households, with the cutback of 3,021 households (42.56\%)

\subsection{Environmental Change in Kendari Bay and Fisherman Income}

Coastal area of Kendari Bay is an area surrounding Kendari Bay with the length of $3.75 \mathrm{~km}^{2}$ [2]. [17] Based on imaging data of Ikonos satellite image of Kendari recorded in 2003, it appears that the coastal area of Kendari Bay is dominated by ponds and mangrove that surround the coast, particularly the coast in the south side of the city.

However, based on imaging data of Quick Bird satellite recorded in 2009, it appears that in some locations, there have been changes in land use of mangroves and ponds areas into business center. In addition, there was also land conversion of mangrove area into residential area. The changes in land cover will cause negative impact on society and the environment. The loss of mangrove vegetation will cause a reduction in fishing communities as a source of income, as mangrove area is usually used for fish, shrimp and crab spawn (Jaya, 2013).

Based on land cover data in 2003, the most dominant settlement area located in the northern part of the bay, that is in Kendari districts and West Kendari districts. Similarly, primary and secondary forest areas were also located in the region. The area of ponds and mangrove forests were dominant in the south of Kendari Bay. Based on the analysis of the land cover map in 2009 compare with the land cover map of 2003, the value of land cover changed, as it explained in Table 3

Table 3. Changes in land cover in coastal area of Kendari Bay in 2003 and 2009.

\begin{tabular}{llll}
\hline \multirow{2}{*}{ Land Cover } & Area (Ha) & $\begin{array}{l}\text { Change } \\
\text { (Ha) }\end{array}$ \\
\cline { 2 - 3 } & Year 2003 & Year 2009 & -56.57 \\
\hline Mangrove & 182.00 & 125.43 & -205.50 \\
Pond & 330.96 & 125.46 & +292.00 \\
Settlements & 382.37 & 674.37 & +68.31 \\
Swamp & 17.63 & 85.94 & +1.98 \\
Body of Water & 22.31 & 24.29 & -124.84 \\
Secondary Forest & 202.57 & 77.73 & -3.28 \\
Primary Forest & 4.73 & 1.45 & \\
Total & 1.142 .57 & 1.114 .67 & \\
\hline
\end{tabular}

Source: [17]

Based on Table 3, land cover had changed significantly in the coastal area of Kendari Bay between 2003 and 2009. The biggest decline on pond areas occurred for 205.50 ha and 
land cover of mangroves decreased by 56.57 ha and primary forest decreased for 3.28 ha. On the other hand, there was an extent on land cover in coastal area of Kendari Bay, in which housing area have increased to 292 ha, there by increased the swamp area into 68.31 ha due to accumulation of coastal area of Kendari Bay for housing area.

Kendari Bay is susceptible to pollution. This condition is much influenced by semi-closed form of the bay, and all land activities will be directed towards the inner side of Kendari Bay coast. The absence of sewer leading towards the sea the coastal area of Kendari Bay cause pollutant storage in the form of beach sediment. Sources of water pollution can be identified from variety of sources including fishing industry, public ports, fishing ports, hotel waste, hospital waste, household waste, mining and other activities. Furthermore, activities through out the watershed towards Kendari Bay and the activities of sea transportation and fisherman.

The area of Kendari Bay has been shrinking rapidly within the last 50 years and facing serious problems that could threaten its long-term survival and function, as presented in Table 4.

Table 4. Changes in the area, volume and depth of the Kendari Bay in 19602010.

\begin{tabular}{llll}
\hline Period & Size $(\mathbf{H a})$ & Sediment Volume $\left(\mathbf{m}^{\mathbf{3}}\right)$ & Depth $(\mathbf{m})$ \\
\hline 1960 & 1.675 & 1.084 .285 & 11.7 \\
1992 & 1.172 & 34.697 .142 & 7.7 \\
1995 & 1.125 & 37.950 .000 & 7.3 \\
2000 & 1.084 & 41.838 .333 & 6.5 \\
2005 & 1.006 & 49.553 .366 & 4.7 \\
2010 & 969 & 55.304 .766 & 3.1 \\
\hline
\end{tabular}

Source: [18]

Based on Table 4, in 1960, Kendari Bay covered the area of 1,675 ha, in 1995 decreased into 1,125 ha, then in 2000 the area of Kendari Bay decreased to 1,084 ha, and in 2010 Kendari Bay area left for 969 ha. Overall, in 2010 Kendari Bay area was reduced by $42.15 \%$ compare with the condition in 1960. The decline in Kendari Bay was caused by sedimentation, in which sedimentation volume in 1960 amounted to $1,084,285 \mathrm{~m}^{3}$, then in 2010 , sedimentation volume reached 55,304,766 $\mathrm{m}^{3}$. The sedimentation sourced from Wanggu, Kambu, and Mandonga riversas it contributed the highest sedimentation, approximately $1,330,281 \mathrm{~m}^{3} /$ year with the rate of shallowing $0.207 \mathrm{~m} /$ year. It is expected in the next 10 years the depth of Kendari Bay will be only 1.2 to 3 meters, then turned into a land with the area of 923.4 hectares, so that the water area of the Kendari Bay will be only 197.1 hectares. Further, it is predicted that in 24 years, the depth will be 1-10 meter then turned into a land with the area of 1091.1 hectares, so the rest of Kendari Bay area will be 18.8 hectares.

According [7], Kendari Bay shallowing is caused by: (1) sedimentation caused by construction activities, (2) sedimentation cause by soil erosion in Bay Watershed, and (3) sedimentation of garbage. Further, according [19],75\% of bay damage is caused by development activities and the shallowing of Kendari Bay is caused by sedimentation derived from the construction of road infrastructure. Meanwhile, according [18] the shallowing of Kendari Bay mainly caused by land clearing activities in 1978-1995, the time when transmigrant worked with intensive agriculture without conducting soil conservation for the local population. Further, [18] explained that spontaneous transmigration program from South Sulawesi province and Ladongi districts Kolaka by converting forest into cocoa plantation/agroforestry in the upstream of Wanggu watershed also causing bay shallowing. The phenomena is also caused by bad habit maintained by Kendari people, as in general, they usually throw garbage into the Bay because during 1960-1995 there had been no garbage waste management, even waste transportation system was limited. Sedimentation is the main reason of Kendari Bay shallowing, which derived from the beach reclamation in 1985-1995 and development of road infrastructure, Baypass road surrounding Kendari Bay area and the construction of new roads in the city of Kendari intensively and Baypass road along Wanggu river side, which connects Kendari with Wolter Monginsi airport (now called the Halu Oleo airport). Moreover, sand mining in the middle and downstream of Wanggu and Kambu rivers continues for the establishment of bridge infrastructure, drainage and housing in the area of Wanggu watershed.

Land conversion and sedimentation in Kendari Bay also cause changes in water quality on Kendari Bay. The measurement result of water parameters in Kendari Bay at three points (station) shows that the water quality parameters at three stations exceed the permitted environmental standards in 2000, 2003 and 2010. It indicates that water quality in Kendari Bay has undergone environmental pollution. Water quality at three measuring stations in Kendari Bay described in Table 5.

Table 5. Water quality at three measurement stations in Kendari Bay.

\begin{tabular}{|c|c|c|c|c|c|c|c|c|c|c|c|c|}
\hline \multirow{3}{*}{ No } & \multirow{3}{*}{ Parameter } & \multirow{3}{*}{ Unit } & \multicolumn{9}{|c|}{ Station } & \multirow{3}{*}{$\begin{array}{l}\text { Quality } \\
\text { Standard }\end{array}$} \\
\hline & & & \multicolumn{3}{|l|}{$\mathbf{A}$} & \multicolumn{3}{|l|}{ B } & \multicolumn{3}{|l|}{$\mathbf{C}$} & \\
\hline & & & $2000^{*}$ & $2003^{\text {** }}$ & $2010^{* * * *}$ & $2000^{*}$ & $2003^{* *}$ & $2010^{* * * *}$ & $2000^{*}$ & $2003^{* *}$ & $2010^{* * * *}$ & \\
\hline 1 & $\mathrm{pH}$ & $\mathrm{mg} / \mathrm{l}$ & 5.9 & 7.7 & 7.4 & 8.1 & 8.1 & 8.5 & 8.1 & 8.1 & 8.7 & $6-9$ \\
\hline 2 & Temperature & ${ }^{\circ} \mathrm{C}$ & 29.1 & 29.0 & 29.5 & 28.8 & 28.0 & 28.5 & 28.3 & 28.3 & 29.0 & Natural \\
\hline 3 & DO & $\mathrm{mg} / 1$ & 4.4 & 3.0 & 2.6 & 5.5 & 3.5 & 3.2 & 5.5 & 4.5 & 3.9 & $>4$ \\
\hline 4 & COD & $\mathrm{mg} / 1$ & - & 70.0 & 80.2 & - & 80.0 & 82.5 & - & 50.0 & 60.5 & $<80$ \\
\hline 5 & $\mathrm{BOD}_{5}$ & $\mathrm{mg} / \mathrm{l}$ & 4.2 & 2.8 & 4.9 & 1.2 & 2.5 & 4.6 & 3.2 & 3.0 & 5.5 & $<4.5$ \\
\hline
\end{tabular}

Description: Station $\mathrm{A}=$ upper Bay, Station $\mathrm{B}=$ the middle of the Bay and Station $\mathrm{C}=$ the outer end of the Bay

Source: ${ }^{*}[4] ;{ }^{* *}[18] ;{ }^{* * *}[18] ;{ }^{* * * *}[20]$ 
Environmental pollution in Kendari Bay as the result of land conversion and sedimentation causea decrease in biodiversity and abundance of fish found in the Bay of Kendari. According [7], the shallowing of Kendari Bay results in the decrease of the biodiversity and fish availability. Several kinds fish found living in the habitat of Kendari Bay such as baronang, kembung, selar, layang, ekor kuning, ternbang, pisang-pisang, teri, julung-julung, shrimp and crabs are getting more difficult to be found by fishermen in coastal area of Kendari Bay.

The difficulties experienced by the fisherman to get fish in Kendari Bay directly affects their income. Income is the difference between revenue and all expenses incurred during the fishing activity. The income earned by fisherman of Kendari Coast in a month can be observed in Table 6 .

Table 6. Fisherman monthly income in coastal area of Kendari Bay in 2016.

\begin{tabular}{llll}
\hline No & Description & $\begin{array}{l}\text { Amount (IDR / } \\
\text { month) }\end{array}$ & $\begin{array}{l}\text { Average (IDR / } \\
\text { month) }\end{array}$ \\
\hline 1 & Total Revenue (TR) & $187.410 .000,-$ & $3.748 .200,-$ \\
2 & Total Cost (TC) & $118.486 .514,-$ & $2.369 .730,-$ \\
& Income (TR-TC) & $68.923 .486,-$ & $1.378 .470,-$ \\
\hline
\end{tabular}

Sources: processed primary data (2016)

Table 6 shows the average of fishermen income in each fishing operation is IDR 3,748,200/month, while the average total cost in each fishing operation is IDR 2.369.730,-/month, so that the average fisherman monthly income in coastal area of Kendari Bay is IDR 1.378.470,- /month. Land conversion and sedimentation have caused fisherman to move the catchment area to respond the decreasing number of fish in Kendari Bay, and it boosts the operational cost.

\subsection{Fisherman Welfare Analysis}

One of the important factors to assess the impact of environmental change on fisherman is welfare. Environmental changes contribute to the fisherman welfare. Previous research has revealed the relationship of environmental change with difficulty to finding some kinds of fish in Kendari Bay, as well as the decline in the catch, which therefore contributes to social and economic indicators: fishermen income rate. Based on survey result in 2013, fisherman income is below farmer income and the minimum wage of Kendari; as the average of farmer income is IDR $1,800,000 /$ month and city minimum wage is IDR 2,000,000. On the other hand, according to welfare standards issued by World Bank, a person is considered to be poor with the income of less than USD1/capita/day. Based on the exchange rate of IDR to USD in 2016, USD 1 is IDR14,500, so the average per capita of the respondents income was IDR45.949/capita/day or USD3.2/capita/day.

Based on the measurement, the fishermen in coastal area of Kendari Bay is still above the threshold of poverty, it can be observed in Figure 1. Meanwhile, using poverty standard by BPS Kendari, the result shows IDR 255,229/per capita/month [3], indicating that the average fishing income is above the limit line. Based on Table 6, the average income of respondents based on survey results is IDR $1,378,470 /$ capita/month. Thus, despite the difficulty to get fish due to land conversion and sedimentation which affects fishermen's income, but the welfare is above the poverty threshold.
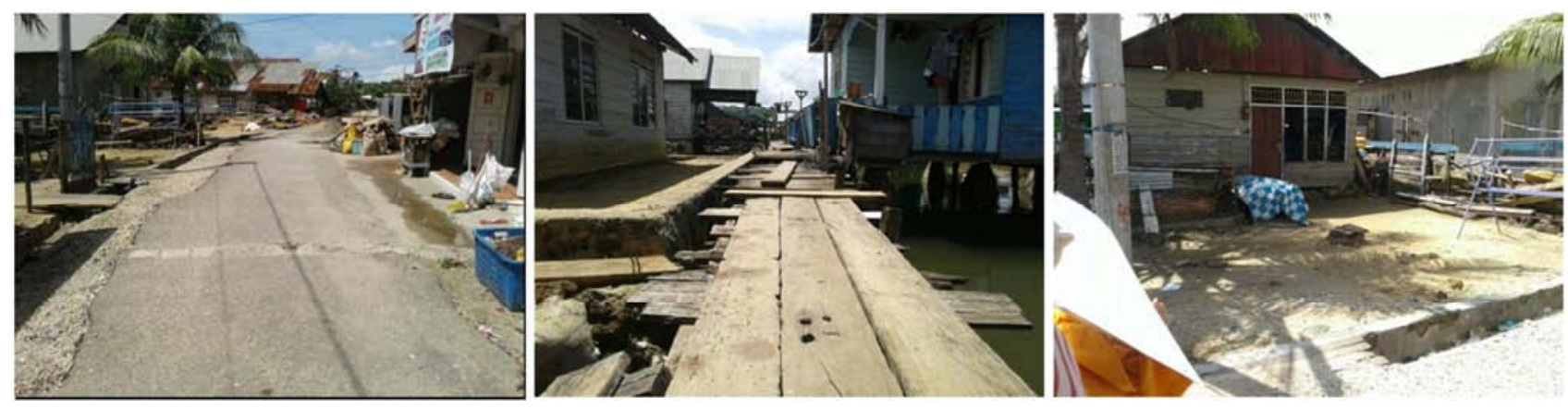

Figure 1. Settlements Fishermen at Kendari Bay.

\section{Conclusion}

Based the research results it can be inferred that coastal area of Kendari Bay is threatened by land conversion and sedimentation which leads to high environmental change and have major implications for the marine and fisheries sources. It causes the fisherman to adapt and look for new catchment area, and it affects their fishing income, while welfare level of fisherman is specifically influenced by fishery resources in coastal area of Kendari Bay, and the welfare level of fisherman is relatively good.

\section{References}

[1] Ramadhan. A dan R. Hafsaridewi. 2012. Dampak Perubahan Lingkungan Terhadap Perkembangan Aktivitas Ekonomi dan Kesejahteraan Masyarakat Pesisir Di Kawasan Segara Anakan. J. Sosek KP Vol. 7 No. 1 Tahun 2012.

[2] Pemerintah Provinsi Sulawesi Tenggara, 2012. Arahan dan penjelasan Gubernur Sulawesi Tenggara tentang Rencana Pengerukkan dan Reklamasi Teluk Kendari Disampaikan pada Pertemuan dengan DPRD Kota Kendari Kendari, 11 Juni 2012. 
[3] BPS Kota Kendari, 2015. Kota Kendari dalam Angka 2015. Badan Pusat Statistik Kota Kendari, Kendari.

[4] Atlas Sumberdaya Pesisir dan Laut Teluk Kendari dan Sekitarnya, 2000. Kerjasama Bappeda Propinsi Sulawesi Tenggara dengan Pusat Kajian Sumberdaya Pesisir dan Lautan (PKSPL) IPB. Bogor.

[5] Bappeda Sulawesi Tenggara, 2011. Laporan Hasil Koordinasi Wilayah Pesisir, Laut dan Pulau-Pulau Kecil Propinsi Sulawesi Tenggara Tahun 2011. Bappeda Sultra. Kendari.

[6] Iswandi. M., M. Ramli., La Baco., A. Alie., Abidin. L., T. Irianto., A. Sanusi., Abu. B., dan Nursalam. S., 2012. Kajian Lingkungan Hidup Strategis (KLHS) dalam Kebijakan, Rencana dan Program (KRP) Revitalisasi Teluk Kendari "Water Front City". Bappeda Provinsi Sulawesi Tenggara. Kendari.

[7] Iswandi, M. 2003. Analisis Dampak Pendangkalan Teluk Kendari terhadap Aktivitas Masyarakat dan Strategi Penanggulangannya. Disertasi Program Studi Ilmu Pengelolaan Sumberdaya Alam dan Lingkungan Program Pascasarjana Institut Pertanian Bogor. Bogor.

[8] BPS Kota Kendari, 2013. Angka Sementara Hasil Sensus Pertanian 2013. Badan Pusat Statistik Kota Kendari, Kendari.

[9] Sevilla, Consuelo G. et. al. 2007. Research Methods. Rex Printing Company. Quezon City.

[10] Arikunto, S. 1998. Prosedur Penelitian: Suatu Pendekatan Praktek. Rineka Cipta. Jakarta.

[11] Hernanto, F. 1991. Ilmu Usahatani. Penebar Swadaya. Yayasan Indonesia. Jakarta.
[12] BPS, 2008. Analisis dan Penghitungan Tingkat Kemiskinan. Jakarta.

[13] Bappeda Provinsi Sulawesi Tenggara, 2015. Rencana Tata Ruang Wilayah Provinsi Sulawesi Tenggara. Bappeda Provinsi Sulawesi Tenggara. Kendari.

[14] Kota Kendari, 2012. Kota Kendari dalam Angka 2012. Badan Pusat Statistik Kota Kendari, Kendari.

[15] BPS Kota Kendari, 2013. Kota Kendari dalam Angka 2013. Badan Pusat Statistik Kota Kendari, Kendari.

[16] BPS Kota Kendari, 2014. Kota Kendari dalam Angka 2014. Badan Pusat Statistik Kota Kendari, Kendari.

[17] Jaya, L. M. G. 2013. Analisis Perubahan Tutupan Lahan Di Wilayah Pesisir Teluk Kendari Menggunakan Citra Satelit Resolusi Tinggi (Kurun Waktu 2003-2009). Forum Geografi, Vol. 27, No. 2, Desember 2013: 183-192.

[18] Alwi. L. 2012. Kajian Dampak Dinamika Penggunaan Lahan Di Das Wanggu Terhadap Sedimentasi Di Teluk Kendari Sulawesi Tenggara. Program Studi Ilmu Pengelolaan DAS Program Pascasarjana Institut Pertanian Bogor. Bogor.

[19] Rachim, M. D, 2011. Teluk Kendari Riwayatmu Kini "Krisis Teluk Kendari" Yayasan Alam Nusantara. Kendari. http://yayasanalamnusantara.blogspot. co.id/2011/09/telukkendari-riwayatmu-kini.html (14 Oktober 2016).

[20] SK Menteri Lingkungan Hidup No. 02/MENKLH/I/1988 tentang Pedoman Penetapan Baku Mutu Lingkungan untuk Kawasan Budidaya Biota Laut (Budidaya Perikanan). 